\title{
Bacterial Reduction of Hand Contamination: Hand Rubbing with Alcohol-Based Solution or Hand Washing with Soap and Water?
}

\author{
Cynthia Pomaa Akuoko ${ }^{1,2^{*}}$ \\ 1.Teaching Staff, Department of Nursing, Christian Service University College. Kumasi, Ghana \\ 2.PhD Candidate, School of Nursing, Queensland University of Technology, Brisbane, Australia
}

\begin{abstract}
Health care-associated infections (HAIs) occur worldwide and affect both developed and developing countries. Hand hygiene, including hand washing (washing hands with plain soap), hygienic hand washing (washing hands with medicated soap) and hygienic hand rubbing (use of antiseptic rubs or solutions) had been recommended as effective in preventing and controlling HAIs. Thus a mini-review was conducted to answer the question is alcoholbased hand sanitizer more effective than standard hand washing with soap and water in bacterial reduction during patient care? Two studies were reviewed which showed statistically significant difference between before and after hand rubbing with alcohol-based and hand washing with soap and water. However bacterial reduction in alcoholbased solution was higher than that of soap and water ( $0.85 \mathrm{vs} 0.58)$.
\end{abstract}

Keywords: hand hygiene, hand washing, hand rubbing, bacterial reduction

DOI: $10.7176 / \mathrm{JHMN} / 67-09$

Publication date:October $31^{\text {st }} 2019$

\section{Background}

Health care-associated infections (HAIs) occur worldwide and affect both developed and developing countries (World Health Organisation (WHO) 2009). It poses a major challenge to the healthcare system and result in significant mortality, morbidity, and economic burden worldwide (Jarvis 1996). Microorganisms accumulate on the hands of Health care workers (HCWs) during patient care and as such contribute in the transmission of these microorganisms to susceptible patients causing infections. Hand hygiene, including hand washing (washing hands with plain soap), hygienic hand washing (washing hands with medicated soap) and hygienic hand rubbing (use of antiseptic rubs or solutions) had been recommended as effective in preventing and controlling HAIs (Larson 1995, Wendt 2001, Pratt et al 2006, NICE, 2012). Therefore adherence to hand hygiene recommendations and guidelines is the most important means to prevent and control the spread of HCAI by HCWs (Pittet 2001). Individual studies have shown the effectiveness of both hand washing with antiseptic soap and water and hand rubbing with alcohol solutions (Parienti et al 2002, Rupp et al 2008, Barrera et al 2011, Yeung et al 2011). Boyce and Pearson (2003) found that "Compared with soap and water hand washing, these products (alcohol-based, waterless hand sanitizers) require less time to use, can be more accessible than sinks, cause less skin irritation and dryness, and when made widely available within an institution, have been shown to improve hand hygiene practices among HCWs". In the studies of both Lona et al (2003) and Yeng et al (2011) in the use of alcohol-based sanitizers in a long-term-care facility, the availability of alcohol-based instant sanitizers increased compliance with hand washing among HCWs. Since alcohol hand rub has been shown to be convenient, a review was undertaken to answer the question

- Is alcohol-based hand sanitizer more effective than standard hand washing with soap and water in bacterial reduction during patient care?

\section{Method}

2.1 Search

A comprehensive search strategy (Table 1) was developed from the various component of the question according to Sackett et al's (2000) question formulating framework PICO; population (HCWs), intervention (alcohol-based solution), comparison (hand wash with soap and water) and outcome (bacterial reduction). The breaking down of the key components resulted in further sub-components (facet analysis) to generate studies that best describe and relate to the question, which was run in Medline, Embase and CINAHL databases from 1946 to present. "HCWs" was not searched as it is very sensitive but not specific. The search strategy included the use of index terms, free text, and Boolean operators 'OR' (combing terms in each part of the question) and 'AND' (combining each of the sets together). The reference lists of the papers retrieved were hand searched for additional papers. 
Table 1. Facet analysis of the question

\begin{tabular}{|c|c|c|c|c|c|c|}
\hline Population & & Intervention & & Comparison & & Outcome \\
\hline \multirow[t]{15}{*}{$\begin{array}{c}\text { Health care } \\
\text { workers }\end{array}$} & \multirow[t]{15}{*}{ AND } & Alcohol-based solution & \multirow[t]{15}{*}{ AND } & Hand wash & \multirow[t]{15}{*}{ AND } & $\begin{array}{l}\text { Bacterial } \\
\text { reduction }\end{array}$ \\
\hline & & OR & & OR & & OR \\
\hline & & Alcohol-based hand gel & & Hand washing & & $\begin{array}{l}\text { Infection } \\
\text { prevention }\end{array}$ \\
\hline & & OR & & OR & & OR \\
\hline & & Alcohol-based hand rub & & $\begin{array}{l}\text { Standard hand } \\
\text { washing }\end{array}$ & & $\begin{array}{l}\text { Infection } \\
\text { control }\end{array}$ \\
\hline & & OR & & OR & & OR \\
\hline & & $\begin{array}{c}\text { Alcohol-based hand } \\
\text { sanitizer }\end{array}$ & & $\begin{array}{l}\text { Traditional hand } \\
\text { washing }\end{array}$ & & \multirow[t]{9}{*}{$\begin{array}{l}\text { Infection } \\
\text { reduction }\end{array}$} \\
\hline & & OR & & OR & & \\
\hline & & Alcohol hand gel & & \multirow{7}{*}{$\begin{array}{c}\text { Regular hand } \\
\text { washing }\end{array}$} & & \\
\hline & & OR & & & & \\
\hline & & Alcohol solution & & & & \\
\hline & & OR & & & & \\
\hline & & Waterless hand gel & & & & \\
\hline & & OR & & & & \\
\hline & & $\begin{array}{c}\text { Water less hand } \\
\text { sanitizer }\end{array}$ & & & & \\
\hline
\end{tabular}

\subsection{Inclusion and Exclusion Criteria}

Primary studies comparing alcohol-based solution and hand wash with soap (either plain or antiseptic) and water and among HCWs were included. The study had to be randomised trial. In order for trials to be included, bacterial reduction had to be its primary outcome measured. The search resulted in 200 citations in which filters such as English Language and humans were applied bringing them down to 6 papers (Figure 1) which 4 were excluded (Table 2). 


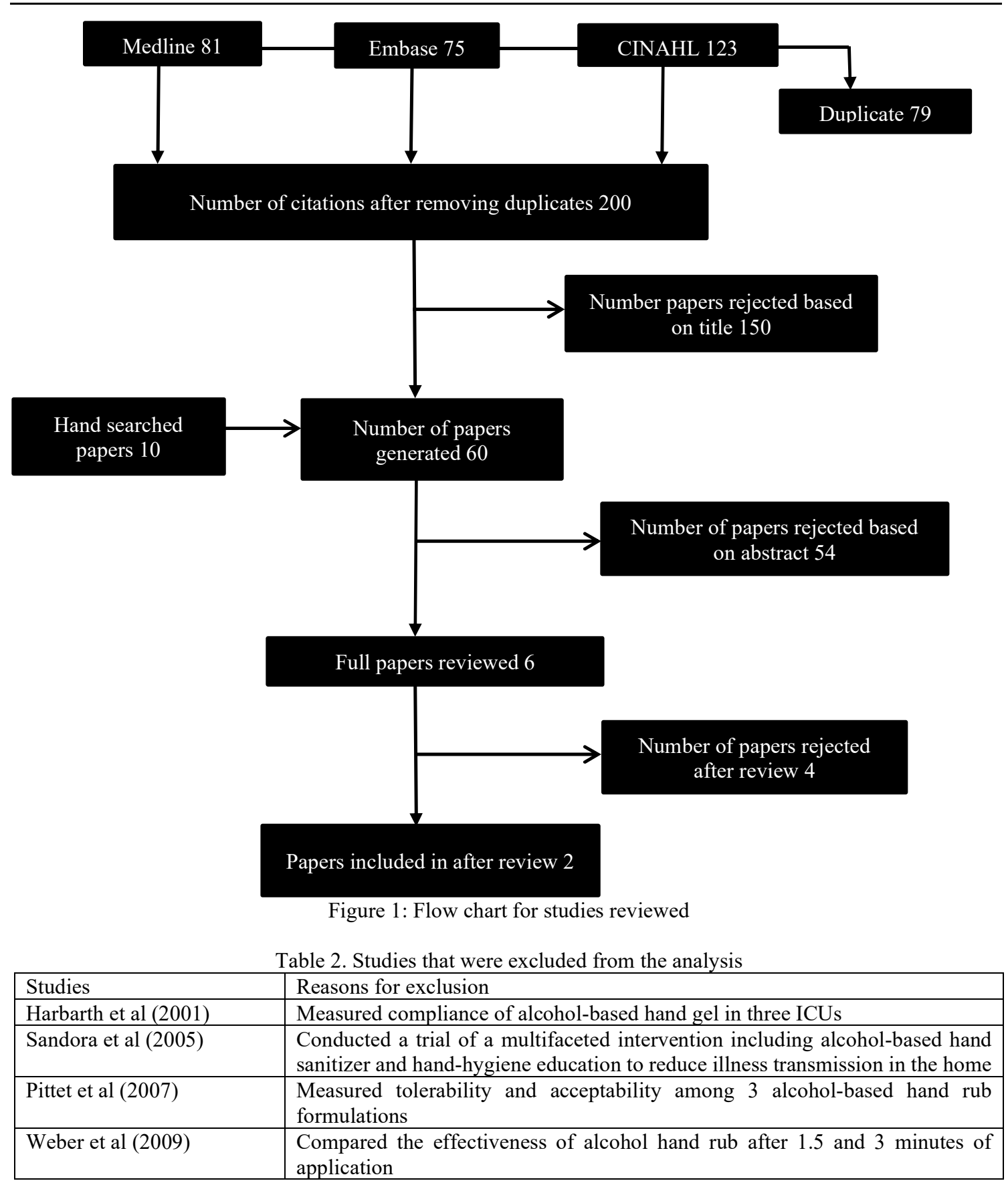

2.3 Methodological Quality of Included Studies

The two studies reviewed included 73participants in total and both compared hand rubbing with alcohol-based solution and hand washing with soap and water. Table 3 gives the description of the main features of the two trials. An appraisal tool (CASP) adapted from Guyatt et al $(1993,1994)$ was used to critically appraise the two trials. 
Table 3. Description of Studies Included

\begin{tabular}{|l|l|l|}
\hline Description & Zaragoza et al (1999) & Girou et al (2002) \\
\hline Study design & $\begin{array}{l}\text { Evaluation blinded RCT } \\
\text { with crossover design }\end{array}$ & Evaluation blinded RCT with parallel groups \\
\hline Sample & $\begin{array}{l}\text { 50 HCWs both permanent } \\
\text { and temporary }\end{array}$ & 23 HCWs both permanent and temporary \\
\hline $\begin{array}{l}\text { Number of HCWs } \\
\text { included in the analysis }\end{array}$ & February to March 1997 & June to July 2000 \\
\hline Period of study & $\begin{array}{l}\text { Hand wash with alcohol-based hand } \\
\text { solution }\end{array}$ & Hand rub with alcohol-based hand solution \\
\hline Intervention & $\begin{array}{l}\text { Hand wash with liquid soap and } \\
\text { water }\end{array}$ & Hand wash with antiseptic soap and water \\
\hline Comparison & $\begin{array}{l}\text { Reduction of bacterial microflora of } \\
\text { hands during regular work in clinical } \\
\text { wards and ICUs }\end{array}$ & $\begin{array}{l}\text { Bacterial reduction of hand contamination } \\
\text { during routine patient care in wards and ICUs }\end{array}$ \\
\hline Outcome measure & Study und & \\
\hline
\end{tabular}

Zaragoza et al's (1999) study undertaken in Spain from February to March 1997, randomly recruited 50HCWs assigned to hand washing with liquid soap or hand rubbing with alcohol-based solution. Girou et al (2002) recruited $23 \mathrm{HCWs}$, assigned hand washing with antiseptic soap and water and hand rubbing with alcohol-based solution to parallel groups in France from June to July 2000. Both studies took imprints from fingertips and palm of participants by researchers in the units without interfering with hand hygiene before and after patient activities. The microbiologists who examined the culture plates and did the reporting of the results were blinded in both trials. This made the results unbiased (Jadad 1998). Blinding of the researchers who collected the samples was not necessary as they did not examine the plates.

Both trials (table 4) were of reasonable methodological quality though not without flaws. The drop-out rate for Zaragoza et al (1999) was 14\% which did not exceed the maximum rate considered to be tolerable by Sackett et al (2000) and so believed do not affect the validity of the results significantly (Gardener \& Altman 1989). The two trials recruited similar participants, conducted in similar settings, received similar treatment at the start of the study as well as similar intervention been implemented. Clinical homogeneity exists between both studies.

Although both studies are clinical trials, Zaragoza et al (1999) used a crossover design while Girou et al (2002) used parallel group design. Girou et al (2002) analysis was based on intention-to-treat and Zaragoza et al (1999) adapted "as treated analysis". Methods of recruitment of HCWs were explicitly stated and random assignment of participants was clearly described but blinding was not clear in both studies. Methodologically some variations exist between both studies but the extent of heterogeneity was not determined and believed do not affect the outcome of both trials.

Table 4. Critical Appraisal of the Studies Included

\begin{tabular}{|l|c|c|}
\hline Items & Zaragoza et al (1999) & Girou et al (2000) \\
\hline Rationale and specific objective stated & Yes & Yes \\
\hline Randomization of participants & Not clear & Yes \\
\hline Detailed intervention given and appropriateness & Yes & Yes \\
\hline Specified outcomes measured & Yes & Yes \\
\hline Determination of sample size (power calculation) & Yes & Yes \\
\hline Sequence generation & Yes & Yes \\
\hline Blind evaluation & Yes & Yes \\
\hline Trial limitations (addressing sources of potential bias) & Yes & Yes \\
\hline $\begin{array}{l}\text { Generalizability (external validity, applicability) of the trial } \\
\text { findings }\end{array}$ & Yes & \\
\hline
\end{tabular}

\section{Findings}

The two studies showed bacterial reduction after hand washing with both soap and water and hand rubbing with alcohol-based solution. Zaragoza et al (1999) reported mean colony forming unit (CFU) of bacterial before as 75 (SD 39) after as 9 (SD 11) for hand rubbing with alcohol-based solution compared to 82 (SD 75) before and 42 (SD 39) after hand washing. Mean CFU of bacterial in Girou et al (2002) before alcohol-based solution was 271 (SD 372) and 232 (SD 331) for soap and water. It reported 35 (SD 59) for alcohol-based solution and 69 (SD 106) for soap and water after their usage. The average reduction of bacterial was $49.6 \%$ for soap and water and $88.2 \%$ for alcohol-based solution (Zaragoza et al 1999). Much difference was not seen in Girou et al (2002) trial, as 73\% for soap and water and $86 \%$ for alcohol-based solution after usage. The difference in the effect size between after the intervention was statistically significant (Table 5). There was a high degree of statistical homogeneity between 
findings from both studies.

Table 5: Results of the reviewed studies

\begin{tabular}{|c|c|c|c|c|c|c|c|c|c|}
\hline & \multicolumn{4}{|c|}{ Alcohol-based solution } & \multicolumn{4}{|c|}{ Soap and water } & \multirow[t]{2}{*}{$\overline{\mathrm{ES}}$} \\
\hline & $\begin{array}{c}\text { Before } \\
\text { Mean } \\
(\mathrm{SD})\end{array}$ & $\begin{array}{l}\text { After } \\
\text { Mean } \\
(\mathrm{SD}) \\
\end{array}$ & $\begin{array}{c}\% \\
\text { reduction } \\
\end{array}$ & $p$ & $\begin{array}{c}\text { Before } \\
\text { Mean } \\
(\mathrm{SD}) \\
\end{array}$ & $\begin{array}{c}\text { After } \\
\text { Mean } \\
(\mathrm{SD}) \\
\end{array}$ & $\begin{array}{c}\% \\
\text { reduction } \\
\end{array}$ & $p$ & \\
\hline $\begin{array}{l}\text { Zaragoza et al } \\
\text { (1999) }\end{array}$ & $\begin{array}{c}75 \\
(39)\end{array}$ & $\begin{array}{c}9 \\
(11)\end{array}$ & 88.2 & $<.001$ & $\begin{array}{c}82 \\
(75)\end{array}$ & $\begin{array}{c}42 \\
(39)\end{array}$ & 49.6 & .002 & 0.85 \\
\hline $\begin{array}{l}\text { Girou et al } \\
(2000)\end{array}$ & $\begin{array}{r}271 \\
(372) \\
\end{array}$ & $\begin{array}{r}35 \\
(59) \\
\end{array}$ & 86.0 & - & $\begin{array}{c}232 \\
(331) \\
\end{array}$ & $\begin{array}{c}69 \\
(106) \\
\end{array}$ & 73.0 & .012 & 0.58 \\
\hline
\end{tabular}

ES=Effect size

\section{Discussion}

Both trials showed statistical significant difference between before and after hand rubbing with alcohol-based and hand washing with soap and water. However bacterial reduction in alcohol-based solution was higher than that of soap and water. The effect size calculated shows that alcohol-based is more effective than soap and water bacterial reduction.

A review undertaken by Picheansathian (2004) showed hand rubbing with alcohol-based solution significantly reduced bacterial more efficiently than did non-medicated soap. Girou et al (2002) used a medicated soap which resulted in 73\% bacterial reduction, however Zaragoza et al (1999) using non-medicated liquid soap recorded $49.6 \%$ reduction but alcohol-based solution was still high in bacterial reduction in both trials $(86 \%$ \& $88.2 \%)$.

Moreover compliance with hand hygiene was improved with the use of alcohol-based solution (Lona et al 2003, Picheansathian 2004, Yeng et al 2011). Alcohol amount in the agent to be tested would contribute to effectiveness of it. In Larson et al's (2001) study, hand rubbing with alcohol-based solution was equivalent to hand washing with antiseptic soap in bacterial reduction. The factor could be attributed to the amount of alcohol in the agent which was $61 \%$ to $75 \%$ in the alcohol-based solution used by Zaragoza et al (1999) and Girou et al (2002).

\section{Conclusion}

The objective of this mini review was to identify which is more effective; alcohol-based solution or soap and water. This review is in line with other studies that support the use of alcohol-based solution in routine patient care as it appears to be more effective than hand washing with soap and water. It is recommended to increase the usage of alcohol-based solution in clinical settings despite the cost as it has been proven to be more effective in reduction of hand contamination, causing less skin irritation and dryness and could be more accessible (Boyce \& Pearson 2003, Picheansathian 2004).

Further research and review is needed to assess the association between the use of alcohol-based solution and soap and water in HCAIs rates among patients. This review is limited in a number of ways. As the author is a novice in research and in doing a review, many flaws could be identified. Also the author assessed and appraised the trails alone which is in contrast to what is been suggested by Sackett et al (2000). Moreover the search of primary studies was conducted by the author alone, making it not without limitations. Time was a crucial factor in this review and so other databases and peer review journals could not be checked. However the findings of this review could not be affected much as it has been proven that alcohol-based solution is more effective than hand washing with soap and water.

\section{References}

Boyce, J.M. \& Pearson, M.L. (2003). Low Frequency of Fires From Alcohol-Based Hand Rub Dispensers in Healthcare Facilities. Infection Control and Hospital Epidemiology 24(8), 618-619.

Barrera, L., Zingg, W., Mendez, F. \& Pittet, D. (2011). Effectiveness of a hand hygiene promotion strategy using alcohol-based hand rub in 6 intensive care units in Colombia. America Journal Infection Control 39, 633639.

Gardner, M. \& Altman, D. eds (1989). Statistics with Confidence: Confidence Intervals and Statistical Guidelines. London: BMJ Books.

Girou, E., Loyeau, S., Legrand, P., Oppein, F. \& Brun-Buisson, C. (2002). Efficacy of hand rubbing with alcohol based solution versus standard hand washing with antiseptic soap: randomised clinical trial. British Medical Journal 325, 1-5.

Guyatt, G.H., Sackett, D.L. \& Cook, D.J. (1993). User's guides to the medical literature. Journal of American Medical Association 270(21), 2598-2601.

Guyatt, G.H., Sackett, D.L. \& Cook, D.J. (1994). How to use an article about therapy or prevention. Journal of 
American Medical Association 271(1), 59-63.

Harbarth, S., Pittet, D., Grady, L., Zawacki, A., Potter-Bynoe, G., Samore, M.H. \& Goldmann, D.A. (2002). Interventional study to evaluate the impact of an alcohol-based hand gel in improving hand hygiene compliance. Paediatric Infection and Diseases Journal 21(6), 489-95.

Jadad, A. \& Enkin, M.W. (2007). Randomised Controlled Trial; Questions, answers and musings. (2nd ed.). Oxford: Blackwell publishing, (Chapters 1, 3 \& 5).

Jarvis, W.R. (1996). Selected Aspects of the Socioeconomic Impact of Nosocomial Infections: Morbidity, Mortality, Cost, and Prevention. Infection control and hospital epidemiology 17(6), 552-5.

Larson, E.L., CIC 1992-1993 \& 1994 APIC Guidelines Committee (1995). APIC Guideline for Hand Washing and Hand Antisepsis in Health-Care Settings. American Journal of Infection Control 23, 251-269.

Mody, L., McNeil, S.A., Sun, R., Bradley, S.F. \& Kauffman, C.A. (2003). Introduction of a waterless alcoholbased hand rub in a long-term-care facility. Infection Control Hospital Epidemiology 24, 165-171.

National Institute for Health Care Excellence (NICE) Clinical Guideline (2012). Accessed on 06/10/2019. https://www.nice.org.uk/guidance/cg139

Parienti, J.J., Thibon, P., Heller, R., Le Roux, Y., Theobald, P.V., Bensadoun, H., Bouvet, A., Lemarchand, F. \& Le Coutour, X. (2002). Hand-Rubbing With an Aqueous Alcoholic Solution vs Traditional Surgical HandScrubbing and 30-Day Surgical Site Infection Rates. A Randomized Equivalence Study. Journal of American decal Association 288(6), 722-727.

Picheansathian, W. (2004). A systematic review on the effectiveness of alcohol-based solutions for hand hygiene. International Journal of Nursing Practice 10, 3-9.

Pittet, D. (2001). Compliance with hand disinfection and its impact on hospital-acquired infections. Journal of Hospital infection 48 (suppl A): S40-S46.

Pittet, D., Allegranzi, B., Sax, H., Chraiti, M-N., Griffiths, W. \& Richet, H., (2007). Double-Blind, Randomized, Crossover Trial of 3 Hand Rub Formulations: Fast-Track Evaluation of Tolerability and Acceptability. Infection control and hospital epidemiology 28(12), 1344-1351.

Pratt, R.J., Pellowe, C.M., Wilson, J.A., Loveday, H.P., Harper, P., Jones, S.R.L.J., McDougall, C. \& Wilcox, M.H. (2006). EPIC 2 National Evidence-Based Guidelines for Preventing Healthcare-Associated Infections in NHS Hospitals in England. Richard Wells Research Centre, Thames Valley University, London.

Rupp, M.E., Fitzgerald, T., Puumala, S., Anderson, J.R., Craig, R., Iwen, P.C., Jourdan, D, Keuchel, J., Marion, N., Peterson, D., Sholtz, L. \& Smith, V. (2008). Prospective, Controlled, Cross-Over Trial of Alcohol-Based Hand Gel in Critical Care Units. Infection control and hospital epidemiology 29(1), 8-15.

Sackett, D.L., Straus, S.E., Richardson, W.S., Rosenberg, W. \& Haynes, R.B. (2000). Evidence-Based Medicine: How to Practice and Teach EBM. London: Churchill Livingstone.

Sandora, T.J., Taveras, E.M., Shih, M-C., Resnick, E.A., Lee, G.M., Ross-Degnan, D. \& Goldmann, D.A. (2005). A Randomized, Controlled Trial of a Multifaceted Intervention Including Alcohol-Based Hand Sanitizer and Hand-Hygiene Education to Reduce Illness Transmission in the Home. Paediatric 116(3), 578-594.

Weber, W.P., Reck, S., Neff, U., Saccilotto, R., Dangel, M., Rotter, M.L., Frei, R., Oertli, D., Marti, W.R. \& Widmer, A.F. (2009). Surgical Hand Antisepsis with Alcohol-Based Hand Rub: Comparison of Effectiveness After 1.5 and 3 Minutes of Application. Infection Control and Hospital Epidemiology 30(5), 420-426.

Wendt, C. (2001). Hand hygiene - comparison of international recommendations. Journal of Hospital Infection 48 (suppl A): S23-S28.

World Health Organization (2009). WHO Guidelines on Hand Hygiene in Health Care. WHO Press. Geneva, Switzerland. Accessed on 06/10/2019 https://www.who.int/gpsc/5may/tools/9789241597906/en/

Yung, W.K., Tam, W.S.W. \& Wong, T.W. (2011). Clustered Randomized Controlled Trial of a Hand Hygiene Intervention Involving Pocket-Sized Containers of Alcohol-Based Hand Rub for the Control of Infections in Long-Term Care Facilities. Infection Control and Hospital Epidemiology 32(1), 67-76.

Zaragoza, M. Sallés, M., Gomez, J., Bayas, J.M. \& Trilla, A. (1999) Hand washing with soap or alcoholic solutions? A randomized clinical trial of its effectiveness. American Journal of Infection Control 27(3), 258261. 